\title{
Technological studies of the use of modifiers in the flotation of calcium-containing minerals
}

\author{
Elena Shepeta $^{1 *}$, Vladislava Ignatkina ${ }^{2}$ and Luiza Samatova ${ }^{1}$ \\ ${ }^{1}$ Mining Institute FEB RAS, 51 Turgenev st., Khabarovsk, 680000, Russia; \\ 2 Federal State Autonomous Educational Institution of Higher Education "National Research \\ Technological University "MISiS” (FGAOU VO NUST “MISiS”), 4, Leninsky Prospect, Moscow, \\ Russia, 119049
}

\begin{abstract}
Using samples of skarn scheelite-sulfide ore from the Vostok-2 deposit, studies were carried out to model combinations of increased dose of inorganic modifiers (sodium carbonate, water glass, sodium sulfide) based on publications by foreign researchers on the achieved positive result in increasing the contrast of the mineral surfaces of scheelite and calcite and their floatability. Testing was carried out according to the standard flowsheet on tap and recycled water. Oxyhydryl collector was sodium oleate of technical acid B-115, dose $250+50 \mathrm{~g} / \mathrm{t}$. The order of feeding modifiers (sequential supply and combination of a mixture of sodium carbonate (bicarbonate) + water glass), the effect of the temperature of the pulp upon contact, the dose of modifiers and the ratio of components in the mixture were studied. The dose of water glass varied from 350 to $1450 \mathrm{~g} / \mathrm{t}$, sodium carbonate (bicarbonate) varied from 0 to $11.5 \mathrm{~kg} / \mathrm{t}$, sodium sulfide up to $4.9 \mathrm{~kg} / \mathrm{t}$. With increased dose of inorganic modifiers, it was not possible to achieve selective depression of calcite and apatite while maintaining effective scheelite flotation. The use of sodium bicarbonate in comparison with sodium carbonate, at the same flow rates, creates a less alkaline $\mathrm{pH}$ in the flotation pulp, which leads to an increase in the concentration of hardness ions $\left[\mathrm{Ca}^{2+}, \mathrm{Mg}^{2+}\right]$ and overdose of the collector. Using combinations of reagents: sodium carbonate (bicarbonate) + water glass, sodium sulfide + sodium hydroxide + water glass, even with a slight increase in the dose of water glass in the mixture, after heat treatment, concentrates of lower quality were obtained, with increased losses of scheelite compared to the factory mode according to the Petrov method.
\end{abstract}

\section{Introduction}

In the scheelite-sulphide ore of the Vostok-2 skarn deposit, the target mineral is scheelite $\left(\mathrm{CaWO}_{4}\right)$ and gangue calcium minerals (calcite $-\mathrm{CaCO}_{3}$, apatite $-\mathrm{Ca}_{5}\left[\mathrm{PO}_{4}\right]_{3}(\mathrm{~F}, \mathrm{Cl})$, single grains of wollastonite $-\mathrm{CaSiO}_{3}$ ), which have similar flotation properties due to the same active calcium cation on the surface on which the collector is adsorbed. The separation of minerals is caused by the different bond strengths of the surface cation with the anion of the crystal lattice. According to the standard technology with a dose of sodium carbonate up to

\footnotetext{
*Corresponding author: elenashepeta56@mail.ru
} 
$\mathrm{pH} 9.8$, hardness less than $1 \mathrm{mg}$-eq/l, water glass $350 \mathrm{~g} / \mathrm{t}$ and sodium oleate $250+50 \mathrm{~g} / \mathrm{t}$, the following enrichment indicators in the main cycle are achieved in laboratory conditions: $\alpha_{\mathrm{WO} 3}>0.6 \%, \alpha_{\mathrm{CaCO} 3} 4-25 \%, \alpha_{\mathrm{Ca} 5}\left(\mathrm{PO}_{4}\right)_{3}(\mathrm{~F}, \mathrm{Cl}) 0.10-0.20 \%$; recovery of calcium minerals, respectively, is as follows: scheelite $85-94 \%$, apatite $70-75 \%$, calcite $30-70 \%$. With a decrease in the mass fraction of scheelite in the range $\alpha_{\text {WO3 }} 0.10-0.6 \%$, the recovery of scheelite is $40-86 \%$, calcite is $65-80 \%$.

Achieving contrast in the hydrophobicity of surfaces of the separated calcium minerals is a rather difficult problem to solve. It is possible to enhance the contrast of flotation of the separated minerals due to the reagent mode. Modifiers are paid much attention in the latest publications. In published studies by different researchers, the same range of reagents was used as modifiers: sodium carbonate (the main regulator of the environment), water glass (the main suppressor), heavy metal salts, and natural polymolecular compounds.

In Foucaud et al. [1], according to the presented recovery curves, higher results were obtained when using a mixture of water glass and salts of polyvalent ions (Fe (II), Zn) in the reagent mode; mixtures of water glass and sodium carbonate.

Methods for adding sodium carbonate with ethoxylated phenols (OP 10), combinations of sodium sulphide, sodium carbonate and water glass in the steaming of rough rare-earth concentrates have been presented for a long time in S.I. Polkin [2].

Chinese researchers Kang J., Liu Yu., Khoso S. Ah. Et al. [3], when upgrading a rough concentrate containing scheelite, wolframite, calcite, fluorite, presented an industrially developed alternative solution to the Petrov method. In the reagent mode of the rough cycle, the dose of the fatty acid collector was $1.5 \mathrm{~kg} / \mathrm{t}$; NaOH $2 \mathrm{~kg} / \mathrm{t}$, in the selection $\mathrm{Na}_{2} \mathrm{SiO}_{3} 95-90 \mathrm{~kg} / \mathrm{t}, \mathrm{Na}_{2} \mathrm{~S} 5-8 \mathrm{~kg} / \mathrm{t}$. With the introduction of sodium sulfide into the steaming, after diluting the steamed product with water to $35 \%$ of the solid and carrying out three cleaning operations, the quality of the $\mathrm{WO}_{3}$ concentrate increased from 57.75 to $66.51 \%$ with an increase in the $\mathrm{WO}_{3}$ recovery from 69.38 to $83.25 \%$.

Previously, the authors published the results of testing the properties of water glass modified with salts of heavy metals, a combination of water glass and $\mathrm{CaCl}_{2}$, the use of $\mathrm{CMC}$, tannin, starch for the flotation activity of calcium minerals, which showed no advantages over water glass in the cycle of obtaining a collective concentrate and selection by the Petrov method [4-6].

The results of industrial tests at Primorskaia Concentrating Factory (PCF) when replacing water glass with a mixture of water glass and ferrous sulfate showed a lack of stability in obtaining the quality of rough and final scheelite concentrates with an increase in scheelite losses.

In their studies, the authors have demonstrated a successful use of higher aliphatic isoalcohols to reduce the flotation activity of calcite while increasing the recovery of scheelite into a froth concentrate [7-8].

However, based on scientific publications by foreign researchers on the achieved results of the contrast in the separation of scheelite and calcite, due to the use of increased dose of sodium carbonate, water glass and sodium sulphide and on a greater availability of inorganic modifiers than oxyhydryl nonionic surfactants, studies on the combination of these modifiers for ores of the Vostok-2 deposit were carried out.

\section{Materials and Methods}

The effect of a combination of environment modifiers and a water glass depressor on the floatability of calcium-containing minerals from the Vostok-2 deposit was tested according to the standard flotation scheme. The scheme of the rough cycle included the rough scheelite flotation and scavenge flotations (flotation for 10 minutes, cell volume $1.0 \mathrm{l}$, pulp temperature [T] during agitation with reagents and flotation $28-40^{\circ} \mathrm{C}$ ) and cleaning of 
combined concentrates (flotation for $5 \mathrm{~min}$, cell volume $0.5-0.31, \mathrm{~T}-22^{\circ} \mathrm{C}$ ). A pulp of the skarn ore was conditioned with reagents for $2 \mathrm{~min}$.

Methodology for upgrading the rough concentrate: thickening (15 minutes in a 2-liter glass, water column height $-190 \mathrm{~mm}$ ), steaming in a water bath (time $(\mathrm{t})-60 \mathrm{~min}, \mathrm{~T}-85$ $90^{\circ} \mathrm{C}$ ), two or three cleaning of the steamed concentrate (volume of cell 0.5-0.3-0.1 1 , flotation for $5 \mathrm{~min}, \mathrm{~T}-20-25^{\circ} \mathrm{C}$ ) and the scavenge flotation for $10 \mathrm{~min}$. Combinations of modifiers during the heat treatment of rough concentrates were introduced into the hot steaming pulp $\left(\mathrm{T}-85^{\circ} \mathrm{C}\right)$.

The studies were carried out using recycled water, a mixture of recycled and tap water ratio is 1:5. When setting up laboratory experiments with ore samples, the initial weight of the portion was 1 kilogram. After grinding (to a content of $70-75 \%$ of the class $-80+0$ microns) and sulphide flotation, the sulphide tailings were divided into 4 weighed portions and in the experiments were feeding the rough scheelite cycle. When sampling flotation products during flotation at the concentration factory, the weight of the test portions was 250 - $350 \mathrm{~g}$ (sulphide flotation tailings), $120-140 \mathrm{~g}$ (rough concentrate). Weighed individual portions of sample were taken from the total sample either by separating with dividers, or by scooping out pulp equal in volume to the weighed portions, with active stirring of the original sample.

Working solutions of flotation reagents used in studies of ore and flotation products were used in the following concentrations, based on the calculation of $100 \%$ of their activity: $10 \% \quad \mathrm{Na}_{2} \mathrm{CO}_{3}$ and $\mathrm{NaHCO}_{3} ; 10-50 \% \quad \mathrm{Na}_{2} \mathrm{~S} ; 5-30 \% \quad \mathrm{Na}_{2} \mathrm{SiO}_{3}$; sodium oleate saponified with alkali in laboratory conditions on a water bath with technical oleic acid B115 (activity 98\%); the concentration of the collector's working solution being 5\%. When preparing a combination of reagents $\mathrm{Na}_{2} \mathrm{CO}_{3}$ and $\mathrm{Na}_{2} \mathrm{SiO}_{3}$, the calculated amount of sodium carbonate solution was introduced into the water glass solution, the components of the mixture were mixed for 3 minutes, and then fed into the pulp, or the mixture was in contact for a day. In a mixture of $\mathrm{Na}_{2} \mathrm{SiO}_{3}$ and $\mathrm{NaHCO}_{3}$, on the contrary, water glass was introduced into a sodium bicarbonate solution, otherwise a precipitate formed. Solutions of different combinations of modifiers, which during testing were introduced into the pulp of the flotation machine, retained their transparency, the agitation with the pulp for $2 \mathrm{~min}$.

\section{Results and Discussion}

L.O. Filippov et al. [9-10] demonstrated that at optimal dose of modifiers of $1.150 \mathrm{~kg} / \mathrm{t}$ of sodium carbonate and $1.225 \mathrm{~kg} / \mathrm{t}$ of water glass (ratio $1: 1.1$ ) with dose of fatty acid collector $200 \mathrm{~g} / \mathrm{t}$, the contrast of the mineral surface of scheelite and calcite increases.

In a number of works, it was noted for a long time that the depressing effect of water glass on many minerals is reduced (or even eliminated) in the presence of sodium carbonate. According to N.A. Yanis [11], desorption of silicic acid products from the surface of minerals by carbonic acid anions occurs, active centers on minerals are restored, providing adsorption of the collector. M.M. Sorokin believed that it would be more correct to speak about the hydrolysis of acid anions rather than about desorption [6].

Table 1 shows the results of ore flotation of the Vostok-2 deposit in the cycle of rough scheelite flotation with the factory pulp taken from the tailings of sulfide flotation $(S$ tailings). The dose of sodium carbonate (sodium bicarbonate) varied from 0 to $3.3 \mathrm{~kg} / \mathrm{t}$, water glass into rough flotation varied from 350 to $1,450 \mathrm{~g} / \mathrm{t}$, into cleaner flotation it was $100 \mathrm{~g} / \mathrm{t}$, the dose of sodium oleate was constant $250+50 \mathrm{~g} / \mathrm{t}$ (rough and scavenge flotation). 
Table 1. Influence of environment modifiers and their mixture with water glass on the floatability of calcium-containing minerals in the rough cycle

\begin{tabular}{|c|c|c|c|c|c|c|c|}
\hline \multirow{3}{*}{ 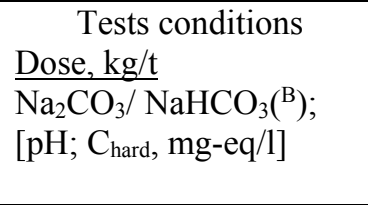 } & \multicolumn{5}{|c|}{ Rough scheelite concentrate } & \multicolumn{2}{|c|}{ Tailings } \\
\hline & \multirow{2}{*}{$\begin{array}{c}\text { Yield } \\
\%\end{array}$} & \multirow{2}{*}{$\begin{array}{c}\text { Assay } \\
\% \\
\mathrm{WO}_{3}\end{array}$} & \multicolumn{3}{|c|}{ Recovery, \% } & \multirow{2}{*}{$\begin{array}{c}\text { Assay } \\
\% \\
\mathrm{WO}_{3}\end{array}$} & \multirow{2}{*}{$\begin{array}{l}\text { Reco } \\
\text { very, } \\
\% \\
\mathrm{WO}_{3}\end{array}$} \\
\hline & & & $\mathrm{WO}_{3}$ & $\mathrm{CaCO}_{3}$ & $\mathrm{P}$ & & \\
\hline \multicolumn{8}{|c|}{ Stailings of PCF with mass fraction $\mathrm{WO}_{3}-0.69 \%, \mathrm{CaCO}_{3}-4.60 \%, \mathrm{P}-0.21 \%$} \\
\hline \multicolumn{8}{|c|}{ Recycled water $(p H-8.7)+$ tap water $(p H-7.0) ;$ water glass dose $350 \mathrm{~g} / \mathrm{t}$} \\
\hline \multicolumn{8}{|c|}{ Separate sequential feed of reagents } \\
\hline $0 ;[\mathrm{pH}=$ & 3.28 & 12.83 & 61.24 & 26.01 & 19.04 & 0.15 & 19.64 \\
\hline $0.21 ;[9.0 ; 2.6]$ & 6 & 9 & 8 & 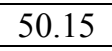 & 9 & 073 & 9.48 \\
\hline $0.40 ;[9.5 ; 1.13]$ & 6.95 & 8.42 & 84.46 & & 49.92 & 0.058 & 7.40 \\
\hline $0.85 ;[9.85 ; 1.0]$ & 7.03 & 8.40 & 85.60 & 58.95 & 54.50 & 0.056 & 7.13 \\
\hline \multicolumn{8}{|c|}{ Mixture (sodium carbonate + water glass; contact of mixture components for 3 min) } \\
\hline $0.23 ;[9.5 ; 2.3]$ & 7.56 & 7.40 & 81.34 & 61.06 & 53.50 & 0.082 & 10.35 \\
\hline $0.91 ;[10.0-1.04]$ & 9.67 & 5.83 & 82.09 & 63.48 & 61.10 & 0.063 & 7.56 \\
\hline \multicolumn{8}{|c|}{ Mixture (sodium carbonate + water glass; contact of mixture components for 1 day) } \\
\hline $0.25 ;[9.5 ; 2.0]$ & 6.54 & 7.98 & 75.35 & 44.14 & 45.98 & 0.11 & 13.85 \\
\hline $0.94 ;[9.8-1.1]$ & 6.80 & 8.25 & 80.86 & 58.06 & 49.80 & 0.10 & 12.68 \\
\hline \multicolumn{8}{|c|}{ Dose of water glass $450 \mathrm{~g} / \mathrm{t}$ (ratio of sodium carbonate : water glass $=1: 1)$} \\
\hline $0.44 ;[9.7 ; 1.39]$ & 4.37 & 12.2 & 77.32 & 38.37 & 35.52 & 0.086 & 11.44 \\
\hline $0.46^{1)} ;[9.78 ; 1.3]$ & 4.92 & 10.2 & 72.84 & 38 & 39.63 & 0.095 & 12.49 \\
\hline $0.44^{2)} ;[9.76 ; 1.8]$ & 4.53 & 9.80 & 63.95 & 31.31 & 34.81 & 0.14 & 18.21 \\
\hline \multicolumn{8}{|c|}{ Dose of water glass $1,450 \mathrm{~g} / \mathrm{t}$ (ratio of sodium carbonate $:$ water glass $=4.4: 1)$} \\
\hline $3.3^{1)} ;[10.5 ; 0.72]$ & 1.24 & 22.8 & 40.95 & 8.04 & 8.39 & 0.17 & 23.63 \\
\hline $3.3^{2)} ;[10.4 ; 1.0]$ & 0.42 & 50.5 & 30.44 & 1.27 & 1.08 & 0.25 & 35.40 \\
\hline \multicolumn{8}{|c|}{ Recycled water $p H-8.8$; ratio of sodium carbonate : water glass $(350 \mathrm{~g} / \mathrm{t})=1(5): 1$} \\
\hline $0.4 ;[9$. & 5.29 & 9.75 & 74.85 & - & - & 0.136 & 18.01 \\
\hline $0.95 ;[10 ; 1.0]$ & 8.08 & 6.67 & 78.05 & - & - & 0.112 & 14.20 \\
\hline $1.65 ;[10.9 ; 0.65]$ & 8.53 & 5.76 & 71.11 & - & - & 0.176 & 22.08 \\
\hline $0.98^{\mathrm{B}} ;[8.2 ; 2.4]$ & 8.20 & 6.54 & 77.85 & - & - & 0.11 & 13.92 \\
\hline \multicolumn{8}{|c|}{ Recycled water; ratio sodium bicarbonate : water glass $(450 \mathrm{~g} / \mathrm{t})=8: 1$} \\
\hline $3.4^{\mathrm{B}} ;[8.96 ; 2.04]$ & 8.92 & 6.29 & 80.93 & - & - & 0.109 & 13.77 \\
\hline $3.55^{1 \mathrm{~B})} ;[9.57 ; 1.4]$ & 15.84 & 3.58 & 82.24 & - & - & 0.10 & 11.08 \\
\hline $3.4^{2 \mathrm{~B})} ;[9.60 ; 1.68]$ & 15.45 & 3.57 & 84.01 & - & - & 0.077 & 8.64 \\
\hline
\end{tabular}

Notes: ${ }^{1)}$ contact of mixture components for $3 \mathrm{~min} ;{ }^{2)}$ contact of mixture components for 1 day; $\mathrm{B}-$ bicarbonate; $\mathrm{C}_{\text {hard. }}$ - hardness ion concentration.

In the absence of sodium carbonate in the flotation pulp, a rough concentrate with an assay of tungsten trioxide $13 \%$, scheelite recovery $60 \%$, apatite and calcite recovery 20 $26 \%$ was separated. An increase in the dose of sodium carbonate to $850 \mathrm{~g} / \mathrm{t}$ led to the achievement of the optimum for scheelite pulp pH 9.8, a hardness of $1 \mathrm{mg}$-eq/1 and an increase in the yield of the rough concentrate. The recovery of scheelite increased up to $85 \%$, calcium impurities up to $55-59 \%$.

In the combinations of a mixture of sodium carbonate (bicarbonate) and water glass, with different contact times of the components in the mixture, the tendency for the behavior of calcium minerals remained, as with the successive supply of reagents. Scheelite recovery ranges from $75-82 \%$.

The reagent mode of the technology: the dose of sodium carbonate in a combination of $3.3 \mathrm{~kg} / \mathrm{t}$ and water glass of $1.450 \mathrm{~g} / \mathrm{t}$ (daily contact of the mixture components) made it 
possible to separate a conditioned scheelite concentrate. This mode is an alternative to the Petrov method, but at the same time, scheelite recovery being 30\%. According to the standard scheme, for a given quality of the final concentrate, scheelite recovery is $88 \%$ (see Table 2).

The figure shows the results of the influence of sodium carbonate dose up to $11.4 \mathrm{~kg} / \mathrm{t}$ at constant dose of water glass $350+100 \mathrm{~g} / \mathrm{t}$ and sodium oleate $250+50 \mathrm{~g} / \mathrm{t}$ in two temperature modes of pulp contacts with reagents 28 and $40^{\circ} \mathrm{C}$.
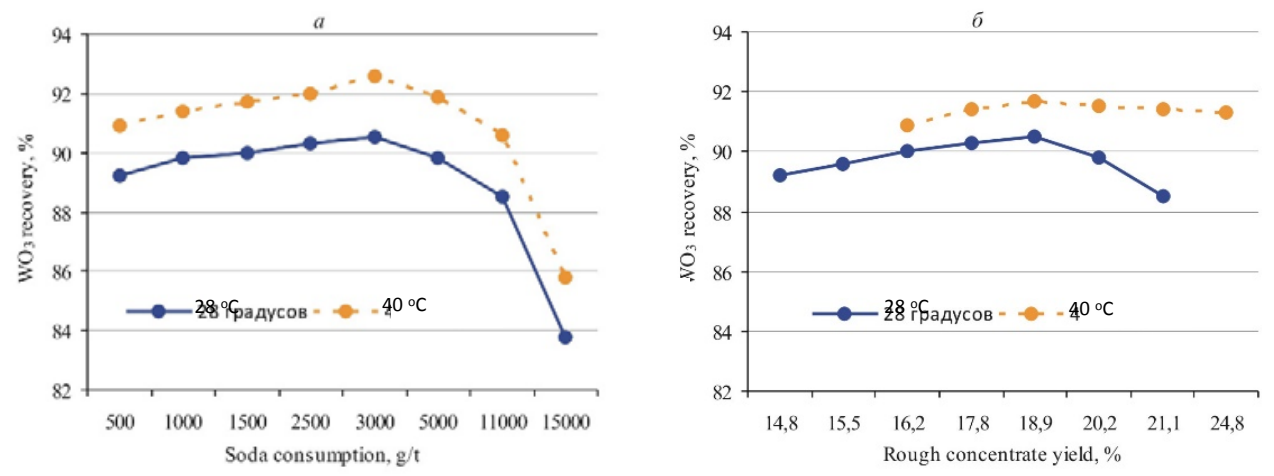

Fig. 1. Influence on the parameters of $\mathrm{WO}_{3}$ recovery into rough concentrate of sodium carbonate dose and pulp temperature upon contact with rough flotation reagents (a); the relationship between the extraction of $\mathrm{WO}_{3}$ into the concentrate and the yield of the rough concentrate at different dose of sodium carbonate and temperature of contact with reagents (b)

As can be seen from the figure, the dependence of recovery of $\mathrm{WO}_{3}$ in the rough concentrate on sodium carbonate dose first increases, passes through a maximum, and then gradually decreases. With an increase in the temperature of the pulp contact with reagents up to $40^{\circ} \mathrm{C}$, the maximum is achieved with a lower dose of sodium carbonate $(1.5 \mathrm{~kg} / \mathrm{t} \mathrm{vs}$ $2.9 \mathrm{~kg} / \mathrm{t}$ ). With an increase in sodium carbonate dose (from 0.4 to $11.4 \mathrm{~kg} / \mathrm{t}$ ), the degree of $\mathrm{WO}_{3}$ enrichment decreases from 6 to 4.2. The relationship between the recovery of $\mathrm{WO}_{3}$ and the yield of concentrate from the dose of sodium carbonate (b) shows that when the collective concentrate yield is more than $16-18 \%$, the recovery of $\mathrm{WO}_{3}$ in the rough concentrate practically does not increase at $40^{\circ} \mathrm{C}$, and decreases at $28^{\circ} \mathrm{C}$. An increase in the dose of sodium carbonate leads to an increase in $\mathrm{pH}$ to 11 , a decrease in pulp hardness to $0.3 \mathrm{mg}-\mathrm{eq} / \mathrm{l}$.

The data on upgrading rough concentrate are presented in Table 2. An increase in the contact time of sodium carbonate (bicarbonate) with concentrated water glass (C-30\%) up to a day led to the formation of a gel-like heterogeneous mass and was not used in testing.

From the data in Table 2, it follows that with an increase in the proportion of sodium carbonate in the mixture, a more significant drop in the quality of the concentrate is observed due to an increase in the calcite content. Scheelite recovery for concentrates with the same quality is higher when finishing rough concentrates using the Petrov method than with a combination of modifiers.

In Kang et al. [3], the high technological results achieved in the cycle of selection of the rough concentrate with sodium sulfide are presented. 
Table 2. Influence of modifiers on the flotation of Ca-minerals in the upgrading cycle.

\begin{tabular}{|c|c|c|c|c|c|c|c|c|c|}
\hline \multicolumn{2}{|c|}{ Test conditions } & \multicolumn{6}{|c|}{ Final scheelite concentrate } & \multicolumn{2}{|c|}{$\begin{array}{l}\text { Upgrading } \\
\text { tailings, \% }\end{array}$} \\
\hline \multirow{2}{*}{$\begin{array}{l}\mathrm{C}, \\
\%\end{array}$} & \multirow{2}{*}{$\begin{array}{c}\mathrm{P}, \mathrm{kg} / \mathrm{t} \\
\text { Sodium } \\
\text { carbonate }(\mathrm{B}) \\
+ \text { water glass }\end{array}$} & \multicolumn{3}{|c|}{ Aassy $(\beta), \%$} & \multicolumn{3}{|c|}{ Recovery $(\varepsilon), \%$} & $\beta$ & $\varepsilon$ \\
\hline & & $\mathrm{WO}_{3}$ & $\mathrm{CaCO}_{3}$ & $\mathrm{P}$ & $\mathrm{WO}_{3}$ & $\mathrm{CaCO}_{3}$ & $\mathrm{P}$ & \multicolumn{2}{|c|}{$\mathrm{WO}_{3}$} \\
\hline \multicolumn{10}{|c|}{ Rough concentrate of PCF - mass fraction $\mathrm{WO}_{3}-7 \%, \mathrm{CaCO}_{3}-32.6 \%, \mathrm{P}-1.83 \%$} \\
\hline 2.21 & $0+31.0$ & 39.86 & 12.7 & 2.25 & 91.01 & 9.41 & 32.31 & 0.69 & 5.23 \\
\hline 2.40 & $0+33.6$ & 55.87 & 7.26 & 1.20 & 88.02 & 3.63 & 11.19 & 0.72 & 5.81 \\
\hline 3.00 & $0+38.4$ & 66.11 & 6.41 & 1.30 & 83.80 & 1. & 6.05 & 0.86 & 10.67 \\
\hline 3.00 & $0.8+43.2$ & 62.41 & 9.73 & 1.62 & 82.24 & 2.70 & 7.88 & 0.94 & 11.86 \\
\hline 3.00 & $0.7^{\mathrm{B}}+39.6$ & 58.00 & 11.95 & 1.53 & 84.57 & 3.78 & 8.44 & 0.86 & 10.40 \\
\hline 3.45 & $2.4+43.2$ & 57.89 & 9.89 & 1.27 & 86.35 & 3.15 & 7.26 & 0.78 & 9.44 \\
\hline 3.35 & $2.4^{\mathrm{B}}+44.0$ & 61.07 & 8.78 & 0.73 & 85.10 & 2.62 & 3.88 & 0.77 & 9.40 \\
\hline 4.03 & $7.7+41.6$ & 55.84 & 11.06 & 0.91 & 85.18 & 3.59 & 5.24 & 0.69 & 7.76 \\
\hline 3.50 & $8.4+45.6$ & 42.28 & 13.38 & 1.21 & 85.73 & 5.86 & 9.29 & 0.72 & 7.61 \\
\hline
\end{tabular}

Note ${ }^{\mathrm{B}}$ bicarbonate was used in a mixture with water glass; contact of mixture components for 3 $\min$;

Abbreviations: $\mathrm{C}$ - residual concentration of water glass in steaming, $\mathrm{P}$ - dose of reagents

Sodium sulfide, sodium hydrosulfide, ammonium sulfide are widely used in the process of flotation of sulfide ores, less often in reagent modes of flotation of rare metal ores [2]. In sulfide flotation, soluble sulfide compounds perform a variety of functions from activator to suppressor. In aqueous solutions, according to the data on the solubility of sulfides and the degree of hydrolysis [6], ions and molecules are present [HS $],\left[\mathrm{OH}^{-}\right],\left[\mathrm{Na}_{2} \mathrm{~S}\right],\left[\mathrm{S}^{2-}\right]$. As a result of the oxidation of the sulfide ion in the liquid phase of the pulp, thiosulfate ions $\left[\mathrm{S}_{2} \mathrm{O}_{3}{ }^{2-}\right]$ and sulfate ions $\left[\mathrm{SO}_{4}{ }^{2-}\right]$ can accumulate. The introduction of an environment regulator $\left(\mathrm{Na}_{2} \mathrm{CO}_{3}, \mathrm{NaOH}\right.$ up to $\left.\mathrm{pH} \geq 11\right)$ increases the resistance of sodium sulfide to oxidation [11], and an increase in the pulp temperature during steaming $\mathrm{T}-90^{\circ} \mathrm{C}$ slows down the decomposition of sodium sulfide due to a decrease in the solubility of oxygen in the pulp.

Soluble salts of heavy metals (for example, iron) have a significant effect on the flotation of calcite with a cationic collector in environment of sodium sulfide. It is assumed that the depression in this case in the presence of sodium sulphide is associated with the appearance on the surface of sludge coatings of sulfides formed in the pulp volume, which is facilitated by a low charge of the calcite surface.

It is believed that the oxyhydryl collector on the calcite surface is kept at a temperature of agitation with sodium sulfide up to $\mathrm{T}-90^{\circ} \mathrm{C}$ for 30 minutes [12].

Table 3 shows the results of upgrading rough concentrates at PCF with sodium sulfide. Steaming temperature $90^{\circ} \mathrm{C}$, time 60 minutes. The yield of steaming feed was $7.1 \%$ of the ore, the mass fraction in the original rough concentrate: $\mathrm{WO}_{3}-4,7 \%, \mathrm{P}-1,4 \%, \mathrm{CaCO}_{3}-$ $41,6 \%$, extraction into concentrate from ore: $\mathrm{WO}_{3}-95 \%, \mathrm{P}-71 \%, \mathrm{CaCO}_{3}-64 \%$.

As follows from the data in Table 3 , heat treatment of the rough concentrate without water glass, in the environment of sodium hydroxide and sodium sulfide (experiments 1 3 ) does not allow obtaining the standard quality of the concentrate, the degree of $\mathrm{WO}_{3}$ concentration is 1.1-1.5. Three recleanings of the steamed concentrate were carried out. The introduction of $4.9 \mathrm{~kg} / \mathrm{t}$ into the steaming pulp of water glass (experiments 4) ensured the production of a conditioned $\mathrm{WO}_{3}$ concentrate, recovery being $81 \%$. 
Table 3. The results of concentration in selection in different modes with $\mathrm{Na}_{2} \mathrm{~S}$ and $\mathrm{NaOH}$.

\begin{tabular}{|c|c|c|c|c|c|c|c|}
\hline \multirow[t]{3}{*}{$\begin{array}{l}\text { Test } \\
\text { No. }\end{array}$} & \multirow[t]{3}{*}{$\begin{array}{l}\text { Steaming conditions of rough } \\
\text { concentrate at PCF }\end{array}$} & \multicolumn{3}{|c|}{ Assay (ß), \% } & \multirow{3}{*}{$\begin{array}{c}\text { Recovery } \\
(\varepsilon), \% \\
\mathrm{WO}_{3}\end{array}$} & \multicolumn{2}{|c|}{$\begin{array}{l}\mathrm{WO}_{3} \text { in final } \\
\text { tailings, } \%\end{array}$} \\
\hline & & & & & & $\beta$ & $\varepsilon$ \\
\hline & & $\mathrm{WU}_{3}$ & $P$ & $\mathrm{CacO}_{3}$ & & \multicolumn{2}{|c|}{$\mathrm{WO}_{3}$} \\
\hline 1 & $\mathrm{Na}_{2} \mathrm{SiO}_{3}-0 \mathrm{~kg} / \mathrm{t} ; \mathrm{pH}=9.63$ & 5.59 & 1.49 & 43.95 & 94.25 & 0.50 & 0.39 \\
\hline 2 & $\mathrm{NaOH}-6.4 \mathrm{~kg} / \mathrm{t} ; \mathrm{pH}-12.84$ & 5.34 & 1.46 & 43.07 & 93.35 & 1.90 & 0.64 \\
\hline 3 & $\begin{array}{l}\mathrm{Na}_{2} \mathrm{~S}+\mathrm{NaOH}-(4.9+3.5 \mathrm{~kg} / \mathrm{t}) \\
\mathrm{pH} 13.0^{*}\end{array}$ & 6.87 & 1.61 & 55.23 & 86.48 & 1.12 & 2.01 \\
\hline 4 & $\begin{array}{l}\mathrm{Na}_{2} \mathrm{SiO}_{3}-4.9 \mathrm{~kg} / \mathrm{t} ; \mathrm{C}-4.3 \% \\
\mathrm{pH}-11.4\end{array}$ & 50.53 & 0.75 & 30.93 & 80.65 & 0.59 & 9.40 \\
\hline 5 & $\begin{array}{l}\mathrm{NaOH}+\mathrm{Na}_{2} \mathrm{SiO}_{3}- \\
(3.7+1.3 \mathrm{~kg} / \mathrm{t})\end{array}$ & 30.55 & 0.63 & 58.11 & 72.92 & 0.57 & 6.40 \\
\hline 6 & $\begin{array}{l}\mathrm{Na}_{2} \mathrm{~S}+\mathrm{NaOH}+\mathrm{Na}_{2} \mathrm{SiO}_{3}- \\
(4.9+3.5+3.3 \mathrm{~kg} / \mathrm{t}) ; \mathrm{pH}-13\end{array}$ & 54.00 & 0.64 & 23.16 & 68.37 & 0.73 & 7.70 \\
\hline 7 & $\begin{array}{l}\mathrm{Na}_{2} \mathrm{~S}+\mathrm{NaOH}(\mathrm{pH}-13) \text { steaming; } \\
+\mathrm{Na}_{2} \mathrm{SiO}_{3} \text { steaming } \\
(4.7+3.3+3.2 \mathrm{~kg} / \mathrm{t})\end{array}$ & 41.83 & 1.09 & 38.92 & 73.33 & 0.79 & 8.27 \\
\hline
\end{tabular}

Experiment 7 reproduces the scheme is given in [3], but the results obtained on the

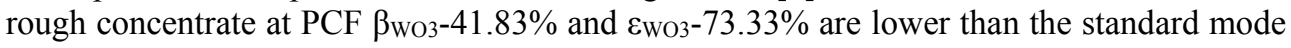
by the Petrov method (experiment 4 ).

\section{Conclusion}

As a result of the studies performed to assess the change in the surface contrast of calcium-containing minerals based on the use of a combination of environment modifiers (sodium carbonate (bicarbonate), sodium hydroxide, sodium sulfide and water glass), it can be stated that it was not possible to achieve selective depression of calcite and apatite while maintaining effective scheelite flotation. The best results for rough scheelite concentrates of PCF were obtained using the standard technology with upgrading according to the Petrov method.

1. The use of sodium bicarbonate in comparison with sodium carbonate, at the same flow rates, creates a less alkaline $\mathrm{pH}$ of the pulp and greater rigidity in the flotation pulp. In open cycle experiments, similar indicators of scheelite enrichment were obtained, but in a closed cycle an increase in the concentration of hardness ions $\left[\mathrm{Ca}^{2+}, \mathrm{Mg}^{2+}\right]$ in the liquid phase middling product pulp will lead to a significant increase in scheelite losses, or an increase in collector dose will be required.

2. Heat treatment of the rough concentrate at $\mathrm{T}=85-90^{\circ} \mathrm{C}$ without water glass does not allow obtaining high-quality scheelite concentrates, a low degree of scheelite concentration of 1.2 has been achieved with a high degree of recovery of all calciumcontaining minerals.

3. On a mixture of sodium carbonate (bicarbonate) and water glass, even with a slight increase in the dose of water glass in the mixture, after heat treatment, concentrates of lower quality were obtained, in comparison with the factory procedure by the Petrov method. With an increase in the proportion of sodium carbonate in the mixture, a more significant decrease in the mass fraction of scheelite in the concentrate is observed.

4. The conditional quality of the concentrate was not obtained from rough scheelite concentrate, in the environment of sodium sulphide and alkali $(\mathrm{pH} \mathrm{13}$, dose $62-43 \mathrm{~kg} / \mathrm{t}$ of steaming feed) without sodium silicate. With water glass and sodium sulphide, the results are significantly lower than using the PCF technology. 
This study was supported by RFBR grant № 17-05-00241.

\section{References}

1. Y. Foucaud, I.V. Filippova, L.O. Filippov, Powder Technology, 352, 501-512 (2019) https://doi.org/10.1016/j.powtec.2019.04.071

2. S.I. Polkin Enrichment of ores and placers of rare and noble metals (Moscow: Nedra, 1987) In Russ.

3. J .Kang, Yu. Liu, S. Ah. Khoso, Yu. Hu, W.Sun, R. Liu, Minerals. 8, 587 (2018) https://doi.org/10.3390/min8120587

4. X.W.F. Jiao, W. Qin, C. Yang, Y.Cui, Y. Wang, Zh. Zhang, H. Song, Colloids and Surfaces A. 602 (2020) https://doi.org/10.1016/j.colsurfa.2020.125006

5. W. Yao, M. Li, M. Zhang, R. Cui, J. Shi, J.Ning, Minerals Engineering, 154 (2020) https://doi.org/10.1016/j.mineng.2020.106423

6. M. M. Sorokin. Flotation. Modifiers. Physical foundations. Practice (Moscow: MISiS 2016) In Russ.

7. V.A. Ignatkina, S.D. Usichenko, F.O. Milovich, Mining Information and Analytical Bulletin. 5, 169-179 (2018) DOI:10.25018/0236-1493-2018-10-0-169-179.

8. E.D. Shepeta., V.A. Ignatkina, L.A. Samatova, Obogashenie Rud, 3, 41-49 (2017) https://doi.org/10.17580/or.2017.03.07.

9. Y. Foucaud, I. Filippova, Q. Dehaine, P. Hubert, L. Filippov, Minerals Engineering, 143 (2019) https://doi.org/10.1016/j.mineng.2019.105896

10. N.A. Yanis. Proceedings of the IV session of the Mekhanobr, 254-273 (1961). In Russ.

11. M.M. Sorokin. Chemistry of flotation reagents. Frothers and Modifiers, (Moscow: Ed. house MISiS, 1979). In Russ. 